\author{
2001 \\ ECOLOGICAL \\ ENGINEERING \\ Ecological Engineering 15 (2000) S157-S170 \\ www.elsevier.com/locate/ecoleng
}

\title{
Spatial and temporal patterns of carbon storage and species richness in three South Carolina coastal plain riparian forests
}

\author{
Laura A. Giese ${ }^{a, *}$, W. Michael Aust a, Carl C. Trettin ${ }^{b}$, Randall K. Kolka ${ }^{c}$ \\ a Department of Forestry, Virginia Polytechnic Institute and State University, Blackshurg, VA 24061, USA \\ ${ }^{\mathrm{b}}$ USDA Forest Service, Southeastern Forest Experiment Station, Center for Forested Wetlands Research, Charleston, \\ SC 29414, USA \\ c Department of Forestry, University of Kentucky, Lexington, KY 40546, USA
}

Received 19 March 1999; received in revised form 1 June 1999; accepted 15 September 1999

\begin{abstract}
The distribution of organic matter within a floodplain is a controlling factor affecting water quality, habitat, and food webs. Accordingly, development of vegetation in the riparian zone can be expected to influence ecosystem functions, and organic matter storage patterns are believed to be indicators of functional recovery in disturbed riparian zones. Our objective was to compare the distribution and allocation of organic matter among microsites within the floodplain and with temporal changes (successional status) associated with community development. Three third order streams in the upper coastal plain of South Carolina were selected. Measurement transects were established across three floodplains of varying successional status, Meyer's branch; a mature riparian hardwood forest; Fourmile branch; a mid-successional riparian forest; and Pen Branch, an early successional riparian forest. Overall, measurements of aboveground biomass, soil carbon, and stand structure indicate that the early and mid successional stands are becoming more similar to the mature stand and that microsite differences within the braided, riparian stream systems are small. (C) 2000 Elsevier Science B.V. All rights reserved.
\end{abstract}

Keywords: Carbon; Disturbance; Forest succession; Riparian; Wetland restoration

\section{Introduction}

In the last 15-20 years, riparian forests have become recognized as important components of the landscape and serve as a vital link between the

\footnotetext{
* Corresponding author. Tel.: + 1-540-2319929; fax: + 1540-2313330.

E-mail address: 1giese@vt.edu (L.A. Giese).
}

aquatic environment and upland ecosystems. Riparian forests are especially critical to maintaining stream health and water quality, and providing the aquatic ecosystem with organic carbon, habitat, bank stabilization, and shade (Mitsch and Gosselink, 1993). Riparian forests also protect waterways from sediment, nutrients, and other surface and groundwater pollutants. Accordingly, maintenance of riparian vegetation or restoration 